56. Hyperchiria varia, Walk. - We have been so long accustomed to call this insect Saturnia io, that we find it difficult to recognize it under its proper name. $\quad$ Io is the name of a South American insect of a different genus.

57. Anisota Stigma, Smith.--In our List as a Dryocampa.

58. Anisota Senatoria, Smith.-Ditto.

59. Anisota Pellucida, Smith.--Ditto.

60. Tolype velleda, Hübn. - In our List as a Gastropacha.

61. Tolype Laricis, Fitch.-Ditto.

62. Clisiocampa disstria, Hübn.- In our List as C. sylvatica, Harris; the former name has the priority.

63. Xyleutes robinie, Harris.-In our List as a Cossus.

\title{
LIST OF DIURNAL LEPIDOPTERA
}

OBSERVED IN THE NEIGHBOURHOOD OF OTTAWA, DURING TIE SEASON OF 1868. BY B. BILLINGS.

1. Papilio turnus, L. - Not common, a few specimens seen late in June and early in July.

2. Papilio asterias, Dr.--Rare. But two specimens seen, one in July, the other in August.

3. Pieris oleracea, Harr.--Plentiful. May, July, August and September.

4. Colias philodice, Godt.-Abundant throughout the season, except in July. The variety of white females was occasionally met with in August.

5. Danais archippus, Harr.-Very common from the last of July to 1st October. A few worn individuals seen about the 1st July. Does this species immigrate? Otherwise what becomes of it for nine months of the year?

6. Limenitis disippus, Godt-_June, rare. July to October very common. From the larva, I obtained a butterfly which remained but five days in the chrysalis state.

7. Limenitis arthemis, Dr.-Plentiful in woods. July and August.

8. Argynnis cybele, Godt.-July, August and September. Not common.

9. Argynnis atlantis, Edw.-Appears to be rare. But two specimens observed.

10. Argynnis myrina, Cram.--Very abundant in June, and plentiful in August and September.

11. Melitea tharos, Cram.-Common. July, August and September.

12. Melitca phaeton, Cram-Dow's swamp, two miles from city limits. Quite plentiful early part of July. 
13. Vanessa J-album, Bdvl. \& Lec.-Rare. But one specimen seen, in August.

14. Vanessa Milberti, Gdt.-Very common from May to October, excepting during the month of June. About the 20 th June, I collected 60 of the larve, which I confined in a single cell in the breeding cage. They refused to take food, and commenced to suspend themselves from the ceiling. Within two days every individual had passed into the pupal state, in which they remained but four days, at the end of which time I found 60 butterfliesnot one, it appears, had failed to come to maturity.

15. Vanessa antiopa, L.-Rare. A single specimen seen in June, and several in October.

16. Grapta progne, Harr.--Rather rare, occasionally met with in open woods throughout the season, from May to October.

17. Grapta faumus, Edw.-Rare. But one specimen observed, in woods late in July.

18. Neonympha eurythris, F.-Common in open woods in July.

19. Hipparchia Boisduvalii, Harr.-Moist places; quite plentiful; July.

20. Erebia nephele, Kirby.-Abundant in fields and thickets in July and August.

21. Chrysophanus Americana, D'Urban.--Plentiful in June, and from the latter part of July to October.

22. Lyccena neglecta, Edw.-Rare. But a single specimen seen, in June.

23. Iyccena lucia, Westw.-Rather rare. June and July.

24. Thecla acadica, Edw.-Rare, on thistle blossoms in July.

25. Pyrameis atalanta, L-Rare. But four specimens seen in August.

26. Pyrameis cardui, L.-From 1st of August to October; very common.

27. Nisoniades brizo, Bdvl, \& Lec.-Plentiful in thickets, in June.

28. Eudamus bathyllus, Bdvl. \& Lec. -Plentiful in June and July.

29. Hesperia metacomet, Harr.-Appears to be rare. A few specimens observed in meadows in July.

30. Hesperia Hobomok, Harr--Abundant in June, not afterwards seen. There does not appear to have been a second brood.

31. Hesperia ahaton, Harr.-Very abundant the latter part of June and early in July. The only indication of a second brood was a single individual seen by me on 3rd September.

32. Hesperia wamsutta, Harr.-Abundant in July and occasionally met with in August.

33. Hesperia mystic, Scudd.--June, July, and August; in meadows; rare.

31. Hesperia Leonardus, Harr.--But a single specimen, seen in a meadow in July.

35. Hesperia Pocahontas, Scudd.-Rare; in thickets ; June and July. 
Besides the above, I have taken previous to the present season :

36. Grapta comma, Lbld. - Which I raised from larvæ found on the hop.

37. Pyrameis huntera, Sm.-Quite common in $\mathbf{1 8 6 3 .}$

38. Thecla falacer, Godt.-Taken on composite flowers in August.

39. Nisoniades catullus, Sm.-Taken within the government grounds at New Edinburgh.

\section{MISCELLANEOUS NOTES.}

Musical LARve.-Noticing Mr. Reed's communication in your issue of Dec. 15, 1868, I thought it might be interesting to note that about twenty similar larvæ were found by me last autumn, on the hickory. Unfortunately, they died before reaching the pupa state. The noise seemed to be produced by contracting the anterior segments, thus rubbing the granulations against each other. Another sphinx larva, which I cannot now identify, emitted a sound resembling that attributed by Kirby \& Spence to the larva of $A$. atropos, on being disturbed. This seemed to be caused by quickly opening and shutting the mandibles - Theodore L. MEAD, New York.

Winter Collecting.- - As an inducement to others to try winter collecting, I would mention that I have taken lately, in addition to many common forms, specimens of Plochionus timidus, Hald., Lymexylon sericeum, Harris (dead), Merinus lcevis, Xylophilus piceus, Lec., and others, with several species of Hemiptera, Hymenoptera, \&c.

I am now making out a list of my species, and think I shall be able to add nearly 300 to our list of Canadian Coleoptera.-J. PeTrit, Grimsby, Ont.

Last Moth of The Season.-On the 29th of Nov., 1868, I captured under a tree a live specimen of Xanthia ferrugineoides, Guen.; the thermometer was then at the freezing point, and it snowed the whole of the rest of the day. I had seen several specimens of the same moth flying about on various occasions during October and November. In Sept., 1865, I took numbers of this species at Cobourg, about plum trees, on the fruit and flying, both in the daytime and at night; it was accompanied by great numbers of Anomis grandipuncta, Guen., and several specimens of Xylina Bethunei, Grote \& Rob. All three species appeared to have a high appreciation of our finer varieties of plums, of which we had a very large crop that year.C. J. S. B.

Depraved taste of a Sphinx.--About mid-day on the 23rd of June, 1868, a very hot day, I was driving through a wood in the township of Trafalgar, when my nostrils were greeted with a horrid odour arising from the carcase of a little dog, floating in a filthy pool, the last remnant of a dried-up stream. The place was perfectly swarming with flies, and to my utter aston- 